Species Diversity, 2006, 11, 1-5

\title{
Peristedion picturatum (Actinopterygii: Peristediidae), a Junior Synonym of Peristedion liorhynchus
}

\author{
Toshio Kawai and Mamoru Yabe \\ Chair of Marine Biology and Biodiversity (Systematic Ichthyology), Graduate School of Fish- \\ eries Sciences, Hokkaido University, 3-1-1 Minato-cho, Hakodate, Hokkaido, 041-8611 Japan \\ E-mail: toshio78@fish.hokudai.ac.jp (TK); myabe@fish.hokudai.ac.jp (MY)
}

(Received 4 April 2005; Accepted 17 October 2005)

\begin{abstract}
Peristedion picturatum McCulloch, 1926 (family Peristediidae) was distinguished from $P$. liorhynchus (Günther, 1872) by a single character, the presence of two bony plates between the anus and first anal ray (vs. three in $P$. $l i$ orhynchus). Our examination of the holotype of $P$. liorhynchus revealed that it also actually has just two bony plates there, not three. Based on a comparison of the holotype and other material of $P$. picturatum with the holotype of $P$. liorhynchus, we conclude that $P$. picturatum is a junior synonym of $P$. liorhynchus.
\end{abstract}

Key Words: Peristediidae, synonym, Peristedion picturatum, Peristedion liorhynchus.

\section{Introduction}

Peristedion picturatum McCulloch, 1926, based on a single specimen from Flinders Island, Australia, has been recognized as a valid species of armored sea robin by Miller (1974) and del Cerro and Lloris (1997), but Paxton et al. (1989), without stating their reasons, regarded $P$. picturatum as a junior synonym of Peristethus liorhynchus Günther, 1872 (now recognized as Peristedion liorhynchus: e.g., Yatou 1982, 1985; Richards 1999; Yamada 2002; Coleman 2003). This latter species has been reported from southern Japan, Indonesia, northern and western Australia, and New Caledonia. Our detailed examination of the type specimens of both species and additional comparative material of $P$. liorhynchus has confirmed their conspecificity, as will be shown below.

Counts and proportional measurements follow Kawai et al. (2004). Standard length is abbreviated as SL. Measurements were made to the nearest $0.1 \mathrm{~mm}$ with a caliper under a microscope. Terminology and counts for bony plates and barbels follow Yatou and Okamura (1985), counting all bony plates in each row. Gill rakers, including all rudiments, were counted on the outer side of the first arch on the right side. Institutional codes follow Leviton et al. (1985).

Material examined. Peristedion liorhynchus (20 specimens): AMS E.4628 (holotype of Peristedion picturatum), $127.5 \mathrm{~mm}$ SL, east of Flinders Island $\left(39^{\circ} 57^{\prime} \mathrm{S}\right.$, $148^{\circ} 20^{\prime} \mathrm{E}$ ), Australia, $182 \mathrm{~m}$ depth, 4 December 1913; AMS I.19205-002 (3), 138.3-161.3 $\mathrm{mm}$ SL, east of Broken Bay $\left(33^{\circ} 33^{\prime} \mathrm{S}, 151^{\circ} 59^{\prime} \mathrm{E}\right)$, Australia, $384 \mathrm{~m}, 26$ May 1976; AMS I.20435-005 (2), 131.0-135.0 mm SL, off North Solitary Island $\left(29^{\circ} 47^{\prime} \mathrm{S}, 153^{\circ} 44^{\prime} \mathrm{E}\right)$, Australia, 438 m, 2 August 1978; AMS I.22807-028 (3), 173.8-183.1 mm SL, $175 \mathrm{~km}$ north of 
Port Hedland (18 $\left.32^{\prime} \mathrm{S}, 118^{\circ} 17^{\prime} \mathrm{E}\right)$, Australia, $204 \mathrm{~m}, 2$ April 1982; AMS I.39994-001 (6), $130.6-150.3 \mathrm{~mm}$ SL, off Bermagui $\left(36^{\circ} 44^{\prime} \mathrm{S}, 150^{\circ} 20^{\prime} \mathrm{E}\right)$, Australia, $375 \mathrm{~m}, 29$ February 2000; BMNH 1871.7.20.53 (holotype of Peristethus liorhynchus), $188.3 \mathrm{~mm}$ SL, Celebes Sea, Manado, Indonesia; BSKU 27393, $222.6 \mathrm{~mm} \mathrm{SL}$, Okinawa Trough $\left(27^{\circ} 00.2^{\prime} \mathrm{N}\right.$, $125^{\circ} 46.0^{\prime}$ E), East China Sea, 302-309 m, 3 March 1978; BSKU 32664, $208.0 \mathrm{~mm}$ SL, Okinawa Trough $\left(25^{\circ} 50.0^{\prime} \mathrm{N}, 124^{\circ} 20.0^{\prime} \mathrm{E}\right)$, East China Sea, 250-290 m, 20 September 1979; HUMZ 71452, $158.8 \mathrm{~mm}$ SL, Port Onahama, Iwaki, Fukushima, Japan, 13 November 1977; HUMZ 79424, 199.3 mm SL, off Cape Ashizuri, Kochi, Japan, 240 m, 30 November 1978.

\section{Results and Discussion}

Günther (1872) reported that the holotype of Peristedion liorhynchus (Fig. 1A) had three bony plates between the anus and the first anal ray, and these were shown in his plate (Günther 1872, pl. 62). McCulloch (1926) distinguished Peristedion picturatum (Fig. 1B) from $P$. liorhynchus because the former has two bony plates between the anus and first anal ray (Fig. 2B). Later, Paxton et al. (1989) treated $P$. picturatum as a junior synonym of $P$. liorhynchus without stating their reasons. The holotype of $P$. liorhynchus actually has two bony plates at the site in question (Fig. 2A), and Günther's (1872) plate is incorrect. Although we found one specimen of AMS I. 19205-002 with just one bony plate there (Fig. 2C), we regard this as an example of intraspecific variation similar to that exhibited by other peristediids (e.g., Peristedion orientale Temminck and Schlegel, 1843; pers. obs.). Yamada and Nakabo (1983) pointed out another instance of variation in bony plate count in the peristediid Satyrichthys rieffeli (Kaup, 1859). Among the material of Peristedion liorhynchus we examined, we found variation in cranial spine shape (Fig. 1) and slight differences in head width (Table 1) as well. We consider such differences in spination to result from growth, and head shape to be variable and not of taxonomic significance. Therefore, we conclude that $P$. picturatum is a junior synonym of $P$. liorhynchus.
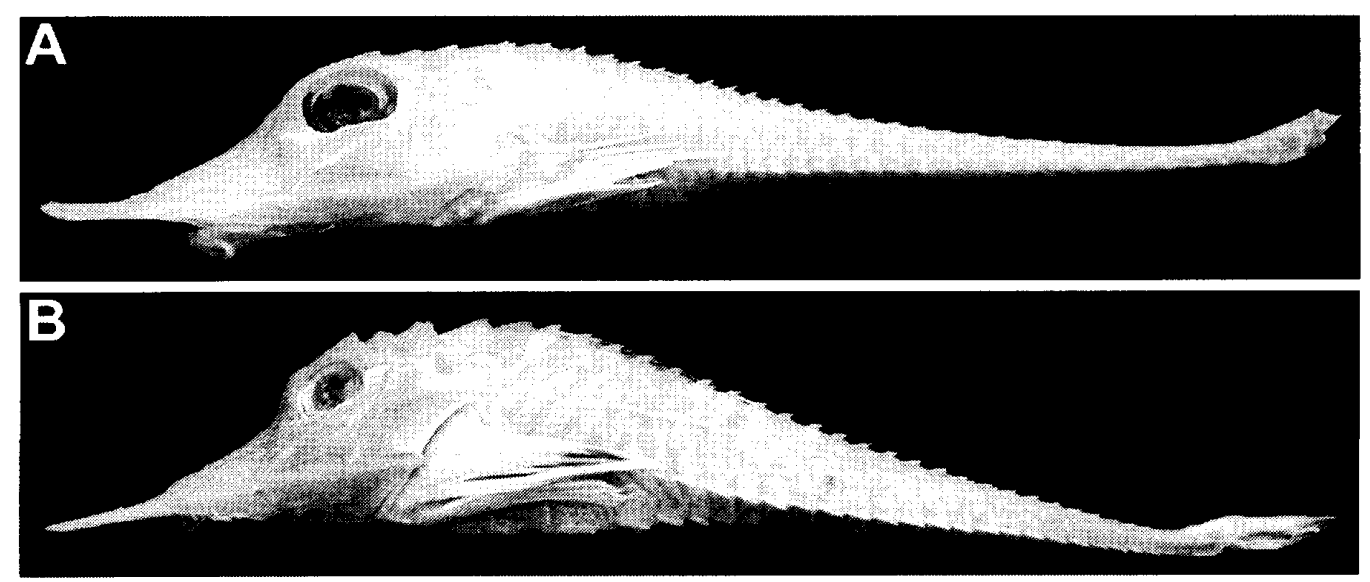

Fig. 1. Holotypes of Peristedion liorhynchus, BMNH 1871.7.20.53, $188.3 \mathrm{~mm}$ SL A, and P. picturatum, AMS E.4628, $127.5 \mathrm{~mm}$ SL B. 


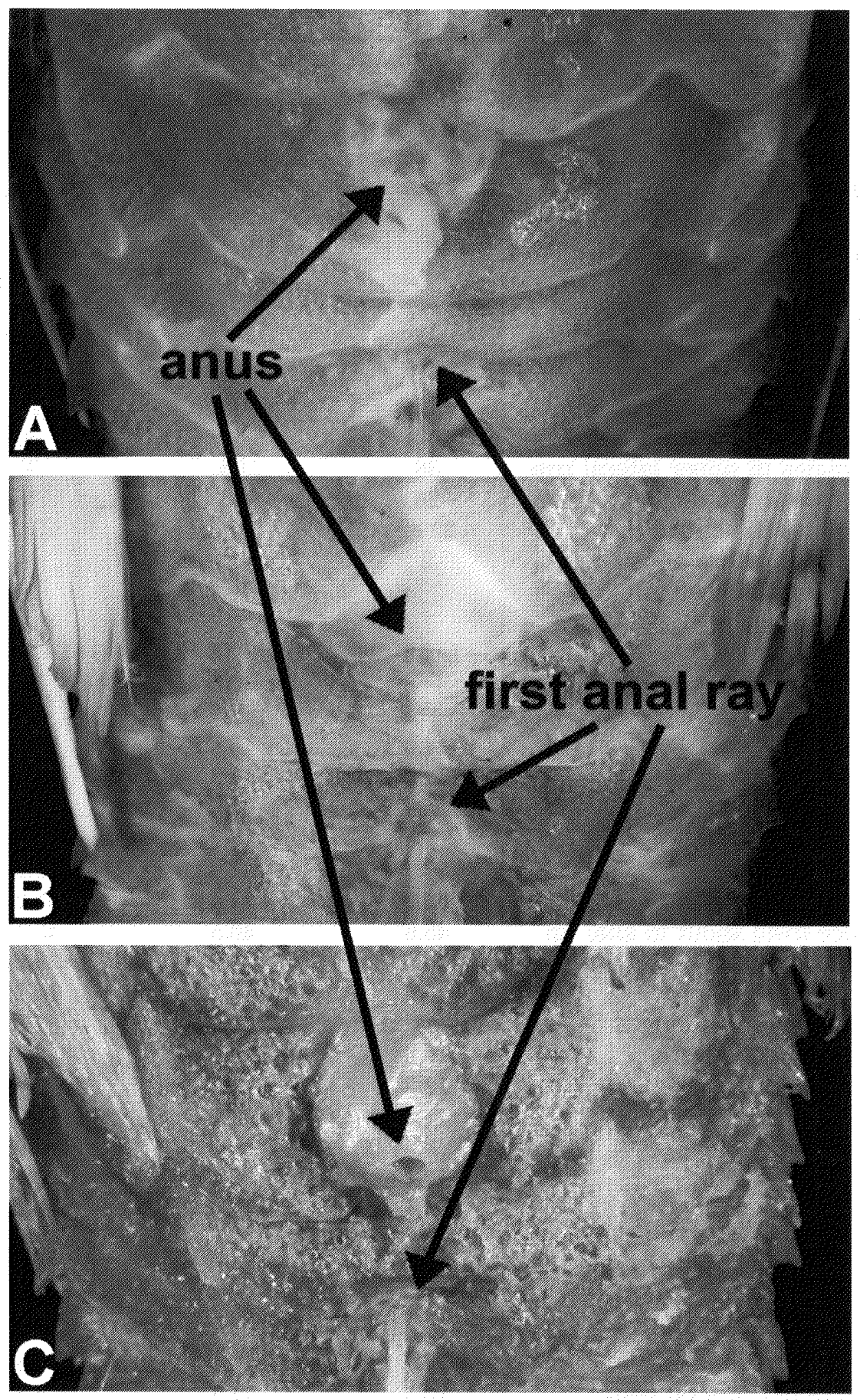

Fig. 2. Ventral view of region between anus and first anal ray. A, Peristedion liorhynchus, BMNH 1871.7.20.53, holotype, 188.3 mm SL; B, P. picturatum, AMS E.4628, holotype, $127.5 \mathrm{~mm}$ SL; C, P. liorhynchus, AMS I. 19205-002, 139.0 mm SL. 
Table 1. Comparison of Peristedion picturatum and P. liorhynchus.

\begin{tabular}{|c|c|c|c|}
\hline & \multirow{2}{*}{$\frac{P . \text { picturatum }}{\text { holotype }}$} & \multicolumn{2}{|c|}{ P. liorhynchus } \\
\hline & & holotype & others $(n=18)$ \\
\hline Standard length (mm) & 127.5 & 188.3 & $130.6-222.6$ \\
\hline \multicolumn{4}{|l|}{ Counts: } \\
\hline Dorsal fin rays & VIII, 21 & VIII, 21 & VII-IX, 20-22 \\
\hline Anal fin rays & 20 & 21 & $20-22$ \\
\hline $\begin{array}{l}\text { Pectoral fin rays } \\
\text { (including two detached rays) }\end{array}$ & 14 & 14 & 14 \\
\hline Pelvic fin rays & I, 5 & I, 5 & I, 5 \\
\hline Principal caudal fin rays & 12 & Broken & $11-12$ \\
\hline Bony plates in dorsal row & 32 & 32 & $30-32$ \\
\hline Bony plates in upper lateral row & 36 & 36 & $36-37$ \\
\hline Bony plates in lower lateral row & 26 & 26 & $25-27$ \\
\hline Bony plates in ventral row & $23+2$ & $23+2$ & $23-24+2$ \\
\hline Bony plates before anus & 2 & 2 & 2 \\
\hline $\begin{array}{l}\text { Bony plates between anus } \\
\text { and first anal ray }\end{array}$ & 2 & 2 & $1-2$ \\
\hline Gill rakers & $5+1+18=24$ & $5+1+16=22$ & $4-5+1+16-20=22-26$ \\
\hline Barbels (lip +chin) & $3+6$ & $3+$ Broken & $3+5-7$ \\
\hline \multicolumn{4}{|l|}{ Measurements (\%SL): } \\
\hline Body depth & 17.0 & 15.1 & $13.6-18.4$ \\
\hline Body width & 13.6 & 14.2 & $12.4-16.1$ \\
\hline Head length & 33.2 & 33.2 & $31.9-34.5$ \\
\hline Head depth & 15.8 & 14.7 & $13.2-17.7$ \\
\hline Head width & 28.1 & 22.9 & $21.8-27.5$ \\
\hline Distance from snout to dorsal fin & 32.2 & 33.4 & $32.2-34.5$ \\
\hline Distance from snout to anal fin & 45.6 & 46.5 & 45.450 .8 \\
\hline Distance from snout to anus & 40.5 & 42.2 & $39.6-45.4$ \\
\hline Snout length & 16.5 & 16.6 & $15.1-17.5$ \\
\hline Rostral projection length & Broken & 7.6 & $7.3-12.3$ \\
\hline Longest barbel length & 10.6 & 10.6 & $8.2-13.9$ \\
\hline Upper jaw length & 12.2 & 12.3 & $10.4-12.6$ \\
\hline Lower jaw length & 13.3 & 12.7 & $12.2-13.6$ \\
\hline Orbital diameter & 7.3 & 8.0 & $7.0-8.2$ \\
\hline Interorbital width & 7.3 & 7.3 & $6.7-8.1$ \\
\hline Pectoral fin length & 16.1 & 17.6 & $13.7-17.2$ \\
\hline $\begin{array}{l}\text { Length of upper } \\
\text { detached pectoral fin ray }\end{array}$ & 20.2 & 22.3 & $17.6-22.6$ \\
\hline $\begin{array}{l}\text { Length of lower } \\
\text { detached pectoral fin ray }\end{array}$ & 17.4 & 18.6 & $15.8-18.0$ \\
\hline Pelvic fin length & 17.3 & 16.9 & $16.3-18.7$ \\
\hline Length of first dorsal spine & 13.3 & 11.7 & $8.7-13.8$ \\
\hline Caudal peduncle length & 10.7 & 9.6 & $8.7-11.0$ \\
\hline Caudal peduncle depth & 2.1 & 2.0 & $2.0-2.5$ \\
\hline
\end{tabular}

\section{Acknowledgments}

We sincerely thank Peter R. Last (CSIRO) for his critical reading of the manuscript and valuable advice, and Kazuhiro Nakaya (HUMZ), Hajime Miyahara 
(HUMZ), and Hisashi Imamura (Hokkaido University Museum) for various suggestions. We also thank Mark McGrouther (AMS), James Maclaine (BMNH), and Hiromitsu Endo (BSKU) for providing the specimens.

\section{References}

del Cerro, L. and Lloris, D. 1997. Gurnard fishes (Scorpaeniformes, Triglidae) from off New Caledonia, with description of five new species. [In: Séret, B. (Ed.) Résultats des Campagnes MUSORSTOM, Vol. 17.] Mémoires du Muséum National d'Histoire Naturelle 174: 91-124.

Coleman, N. 2003. Indo-Pacific Sea Fishes, Northern Australia-Great Barrier Reef. Neville Coleman's Underwater Geographic, Springwood, 144 pp.

Günther, A. 1872. Report on several collections of fishes recently obtained for the British Museum. Proceedings of the Zoological Society of London 1871: 652-675, pls 53-70.

Kawai, T., Imamura, H. and Nakaya, K. 2004. Paraheminodus kochiensis Kamohara, 1957 (Teleostei: Peristediidae), a junior synonym of Paraheminodus murrayi (Günther, 1880), with a comparison of Paraheminodus murrayi and Paraheminodus laticephalus (Kamohara, 1952). Ichthyological Research 51: 73-76.

Leviton, A. E., Gibbs, R. H. Jr., Healand, H. and Dawson, C. E. 1985. Standards in herpetology and ichthyology: part I. Standard symbolic codes for institutional resource collection in herpetology and ichthyology. Copeia 1985: 802-832.

McCulloch, A. R. 1926. Report on some fishes obtained by the F. I. S. "Endeavour" on the coasts of Queensland, New South Wales, Victoria, Tasmania, South and South-Western Australia. Part V. Biological Results of the Fishing Experiments Carried on by the F. I. S. "Endeavour" 1909-14, 5: 157-216, pls 43-56.

Miller, G. C. 1974. Fische des Indischen Ozean. Ergebnisse der ichthyologischen Untersuchungen während der Expedition des Forschungsschiffes "Meteor" in den Indischen Ozean, Oktober 1964 bis Mai 1965. A. Systematischer Teil, XIV, Scorpaeniformes (2) Family Peristediidae. Meteor Forschungsergebnisse. Reihe D, Biologie 18: 61-72.

Paxton, J. R., Hoese, D. F., Allen, G. R. and Hanley, J. E. 1989. Zoological Catalogue of Australia, Vol 7, Pisces, Petromyzontidae to Carangidae. Australian Government Publishing Service, Canberra, xii +665 pp.

Richards, W. J. 1999. Triglidae. Pp. 2359-2382. In: Carpenter, K. E. and Niem, V. H. (Eds) FAO Species Identification Guide for Fishery Purposes. The Living Marine Resources of the Western Central Pacific. Vol. 4. Bony Fishes Part 2 (Mugilidae to Carangidae). FAO, Rome.

Yamada, U. 2002. Peristediidae. Pp. 610-613, 1523. In: Nakabo, T. (Ed.) Fishes of Japan with Pictorial Keys to the Species. English Edition. Tokai University Press, Tokyo.

Yamada, U. and Nakabo, T. 1983. Morphology and ecology of Satyrichthys rieffeli (family: Peristediidae) from Japan. Uo 33: 1-16. [In Japanese with English summary]

Yatou, T. 1982. Peristedion liorhynchus (Günther). Pp. 282-283, 399. In: Okamura, O., Amaoka, K. and Mitani, F. (Eds) Fishes of the Kyushu-Palau Ridge and Tosa Bay. Japan Fisheries Resource Conservation Association, Tokyo.

Yatou, T. 1985. Peristedion liorhynchus (Günther). Pp. 582-583, 725. In: Okamura, O. (Ed.) Fishes of the Okinawa Trough and the Adjacent Waters. Vol. 2. Japan Fisheries Resource Conservation Association, Tokyo.

Yatou, T. and Okamura, O. 1985. Satyrichthys isokawae Yatou et Okamura, sp. nov. Pp. 586589. In: Okamura, O. (Ed.) Fishes of the Okinawa Trough and the Adjacent Waters. Vol. 2. Japan Fisheries Resource Conservation Association, Tokyo. 